\title{
Correction to: Winning at a Losing Game? Side-Effects of Perceived Tournament Promotion Incentives in Audit Firms
}

\author{
Jorien L. Pruijssers ${ }^{1}$ · Pursey P. M. A. R. Heugens ${ }^{2} \cdot$ J. van Oosterhout ${ }^{2}$
}

Published online: 18 September 2018

(c) Springer Nature B.V. 2018

\section{Correction to: Journal of Business Ethics https://doi.org/10.1007/s10551-018-3991-2}

The spelling of the name of the third author was incorrect in the initial online publication. The original article has been corrected.

Pursey P. M. A. R. Heugens

pheugens@rsm.nl

J. van Oosterhout

Joosterhout@rsm.nl

1 Desautels Faculty of Management, McGill University, 1001 Sherbrooke Street West, Suite 334, Montreal H3A 1G5, QC, Canada

2 Department of Strategic Management \& Entrepreneurship, Rotterdam School of Management, Erasmus University, P.O. Box 1738, 3000 DR Rotterdam, The Netherlands 